\title{
The growth, aboveground biomass, crown development, and leaf characteristics of three Eucalyptus species at initial stage of planting in Jepara, Indonesia
}

\author{
PANDU YUDHA ADI PUTRA WIRABUANA ${ }^{1, \vartheta}$, SYAMSU ALAM ${ }^{2}$, JERIELS MATATULA ${ }^{3}$, \\ MOEHAR MARGHIY HARAHAP ${ }^{4}$, YUSANTO NUGROHO ${ }^{5}$, FAHMI IDRIS ${ }^{6}$, ALNUS MEINATA $^{6}$, \\ DEWA AYU SEKAR ${ }^{6}$ \\ ${ }^{1}$ Department of Forest Management, Faculty of Forestry, Universitas Gadjah Mada. Jl. Agro No. 1, Bulaksumur, Sleman 55281, Yogyakarta, Indonesia \\ Tel./fax.: +62-274-548815, `email: pandu.yudha.a.p@ugm.ac.id \\ ${ }^{2}$ Department of Soil Science, Faculty of Agriculture, Universitas Halu Oleo. J1. HEA Mokodompit, Kendari 93231, Southeast Sulawesi, Indonesia \\ ${ }^{3}$ Forestry Field Program, Politeknik Pertanian Negeri Kupang. Jl. Prof. Herman Johanes, Lasiana, Kupang 85011, East Nusa Tenggara, Indonesia \\ ${ }^{4}$ Department of Forest Conservation, Faculty of Forestry, Universitas Sumatera Utara. Jl. Tri Dharma Ujung No. 1, Kampus USU, Medan 20155, North \\ Sumatra, Indonesia \\ ${ }^{5}$ Faculty of Forestry, Universitas Lambung Mangkurat. J1. A. Yani, Banjarbaru 70714, South Kalimantan, Indonesia \\ ${ }^{6}$ Department of Research and Development, Trofsit Institute. Banguntapan, Bantul 55798, Indonesia.
}

Manuscript received: 12 April 2021. Revision accepted: 25 April 2021.

\begin{abstract}
Wirabuana PYAP, Alam S, Matatula J, Harahap MM, Nugroho Y, Idris F, Meinata A, Sekar DA. 2021. The growth, aboveground biomass, crown development, and leaf characteristics of three Eucalyptus species at initial stage of planting in Jepara, Indonesia. Biodiversitas 22: 2859-2869. Industry development, climate change mitigation and renewable energy currently become the most essential challenge in tropical forest management, primarily in Indonesia. The existence of tropical forests is not only managed to maintain the stability of wood supply for commercial industries but also to reduce greenhouse gas emissions in the atmosphere and to generate energy alternatives from tree biomass. To answer this challenge, the development of fast-growing species like eucalyptus can become a good solution. However, the productivity of eucalyptus depends on its adaptability to the site condition. Therefore, understanding site-species interaction becomes the fundamental requirement before planted on a large scale. This study aimed to evaluate the initial performance of eucalyptus species developed in Jepara. An experiment consisted of three different eucalyptus species, i.e., E. alba, E. pellita, and E. urophylla, was established using a randomized complete block design. Sixteen parameters were selected to assess the eucalyptus performance, including survival, height, diameter, biomass accumulation (stem, branches, foliage, and total aboveground), crown length, crown radius, crown projection area, crown ratio, individual leaf area, individual leaf dry weight, specific leaf area, leaf mass area, and leaf area index. The comparison of the mean of tree attributes from each species was examined using ANOVA, followed by HSD Tukey. Results showed that all measured parameters indicated a significant difference among the three species $(p<0.05)$, except for survival, foliage biomass, and crown ratio $(p>0.05)$. The preliminary performance of E. pellita was relatively better than the other two species, mainly related to height $(3.00 \pm 0.21 \mathrm{~m})$, total aboveground biomass $(49.86 \pm 3.60 \mathrm{~kg} \mathrm{ha}-1)$, crown projection area $(2.68 \pm 0.27 \mathrm{~m} 2)$, and leaf area index $(5.76 \pm 0.44)$. Our study concluded the initial performance of E. pellita in Jepara was substantially superior to E. alba and E. urophylla. Nevertheless, continuous evaluation is needed to monitor the consistent performance of those species in the study area.
\end{abstract}

Keywords: Crown projection area, eucalyptus, leaf area index, leaf mass area, specific leaf area

\section{INTRODUCTION}

Integration of industry development, climate change mitigation, and renewable energy diversification currently become the most important challenge in sustainable forest management in tropical regions (Sadono et al. 2021a), including in Indonesia. In the tropics, the existence of forests is not only managed to supply wood demands for commercial industries, but also to reduce carbon emissions in the atmosphere (Sasaki et al. 2016) and to generate energy alternatives from tree biomass (Ferreira et al. 2017). To tackle this challenge, the development of fast-growing tree species can become a win-win solution to achieve triple objectives of maintaining industry viability, reducing carbon emissions, and producing bioenergy (GonzálezGarcía et al. 2016).
In several decades, there are a number of fast-growing tree species developed as plantation forests in the tropics, one of which is eucalyptus. The development of eucalyptus as a major species in plantation forests has been widely conducted in many tropical countries, such as Brazil, Chile, Colombia, Mexico, Thailand, Vietnam, and Indonesia (Aggangan et al. 2013; Hakamada et al. 2017; Acuña et al. 2018; Amezquita et al. 2018; Van Bich et al. 2019; Wirabuana et al. 2020a). Besides having a short rotation period of approximately 5-8 years (Little et al. 2018), the quality of eucalyptus wood suits the requirements of industries, such as for construction materials, pulp and paper, plywood, veneer, and furniture (Forrester 2013; Hii et al. 2017; Nambiar et al. 2018). In addition, the majority of eucalyptus species also have rapid growth due to the more efficient photosynthesis process (Lewis et al. 2011; 
Lima et al. 2019), suggesting that the carbon sequestration in eucalyptus is relatively faster than slow-growing species (Kaul et al. 2010). Therefore, the previous studies also report that the existence of eucalyptus plantations provides a significant contribution to climate change mitigation (Magalhães et al. 2020). Furthermore, a study explains that eucalyptus wood can become a potential source of renewable energy since it has a high calorific value of 4,532-4,661 kcal kg-1 (Simetti et al. 2018). The use of eucalyptus wood for bioenergy has been conducted in some foreign countries, including Brazil, Spain, and Portugal, wherein the development of biomass power plants has been intensively managed (Barreiro \& Tomé 2012; GonzálezGarcía et al. 2016; Cavalett et al. 2018). A study confirms that the use of plant biomass, mainly sourced from eucalyptus wood, results in lower carbon emissions to the atmosphere than fossil fuels like coal as well as oil and gas (Cavalett et al. 2018). All of that evidence provides justification that eucalyptus is highly potential to be developed as plantation forest to simultaneously integrating the goals of industry development, climate change mitigation and renewable energy sources in tropical countries, particularly in Indonesia.

Developing eucalyptus plantations in Indonesia is prospective because it is a native species from this country. Some studies state that there are several eucalyptus species that have natural distribution in the eastern of Indonesia, such as Eucalyptus pellita, E. alba, and E. urophylla (Stanturf et al. 2013; Prasetyo et al. 2017). However, the existence of eucalyptus plantations in Indonesia is still limited wherein most eucalyptus estates are located in Sumatra (Nambiar et al. 2018). Moreover, the objective of eucalyptus management in Indonesia still focuses on supplying raw materials for pulp and paper industry (Prasetyo et al. 2017). This circumstance is quite different from other countries like Brazil, China, and Vietnam in which the presence of eucalyptus plantation becomes the most important plantation forests along in such countries with the development of many processing industries for eucalyptus wood. Those facts indicate that there is a wide opportunity to develop eucalyptus plantations in Indonesia by expanding its area nor improving its downstream industries. However, to develop large-scale eucalyptus plantations, there is a need to enhance the understanding of site-species interaction of eucalyptus stand with its environment in order to obtain high productivity. It is commonly done by establishing an experiment for species trial in several sites which become the priority area for eucalyptus development. In this context, the best species is selected by considering its superior performance to other eucalyptus species.

This study examined the adaptability of three different eucalyptus species, namely E. alba, E. pellita, and E. urophylla planted in the Jepara District, Central Java Province, Indonesia. A preliminary evaluation was undertaken to monitor the growth, aboveground biomass, crown development, and leaf characteristics of those three species at six months after planting. It is a critical period to assess the suitability of species to survive in the site condition (Van Bich et al. 2019; Stuepp et al. 2020;
Wirabuana et al. 2020a) since every eucalyptus species has a habitat preference to support its growth and development. If site condition is not suitable, the species will demonstrate a high mortality rate and low growth performance (Thompson 2013; Maimunah et al. 2018; Aguilos et al. 2020). The species trial of eucalyptus in Jepara was based on the rationale that Jepara has a number of wood processing industries, especially for furniture. Moreover, there are several other forestry industries located near this area, such as pulp and paper, plywood, veneer, and construction, that require a continuous supply of wood raw materials. Interestingly, Jepara has also a power plant that faces a problem related to the coal deficit. This situation provides an opportunity to maximize the potential of eucalyptus for bioenergy. On another side, the development of eucalyptus plantation in Jepara has not yet be conducted until now, even though this species offers a lot of advantages. Most importantly, developing eucalyptus plantations in Jepara is not only directed to support the integration of industry development, climate change mitigation, and renewable energy but also to facilitate the program of ex-situ conservation and to optimize the potential of native species from Indonesia.

\section{MATERIALS AND METHODS}

\section{Study area}

A planting trial was established in community forests located at Srobyong, Jepara District with geographic position in S6 $31^{\prime} 35^{\prime \prime}-6^{\circ} 31^{\prime} 37^{\prime \prime}$ and E110 41'39"$110^{\circ} 43^{\prime 22} 2^{\prime \prime}$ (Figure 1). The planting trial was set up in private land of farmers with an extent of 2 ha. The research site has an altitude of $70 \mathrm{~m}$ above sea level, flat topography was flat with a slope level of $3-8 \%$, the average daily temperature of $29^{\circ} \mathrm{C}$ with a minimum of $22^{\circ} \mathrm{C}$ and a maximum of $34^{\circ} \mathrm{C}$, and the mean air humidity of $84 \%$. It has annual rainfall from 2,246 to $2,446 \mathrm{~mm}_{\text {year }}{ }^{-1}$ during the last five years from 2016 to 2020 with the majority of rainfall is recorded in February around $33.82 \%$ of total rainfall in a year. Dry periods occur for five months from May to September. Soil type is dominated by alfisol with $\mathrm{pH}$ of 5.5 to 6.0. Previously, the vegetation cover consisted of uneven-aged mixed species with irregular distribution and high variation in growth.

\section{Experimental design}

Three different eucalyptus species were examined in this study, i.e., E. alba, E. urophylla, and E. pellita. The planting trial was established in a randomized complete block design (RBCD) with four blocks (i.e., three blocks for continuous monitoring and one block for destructive measurement in specific periods, namely $6,12,24,36,48$, and 60 months). This design was selected to minimize the influence of environmental gradient on eucalyptus performance (Thompson 2013). It was importantly conducted to avoid the biased result due to the impact of site condition, particularly related to soil quality. 


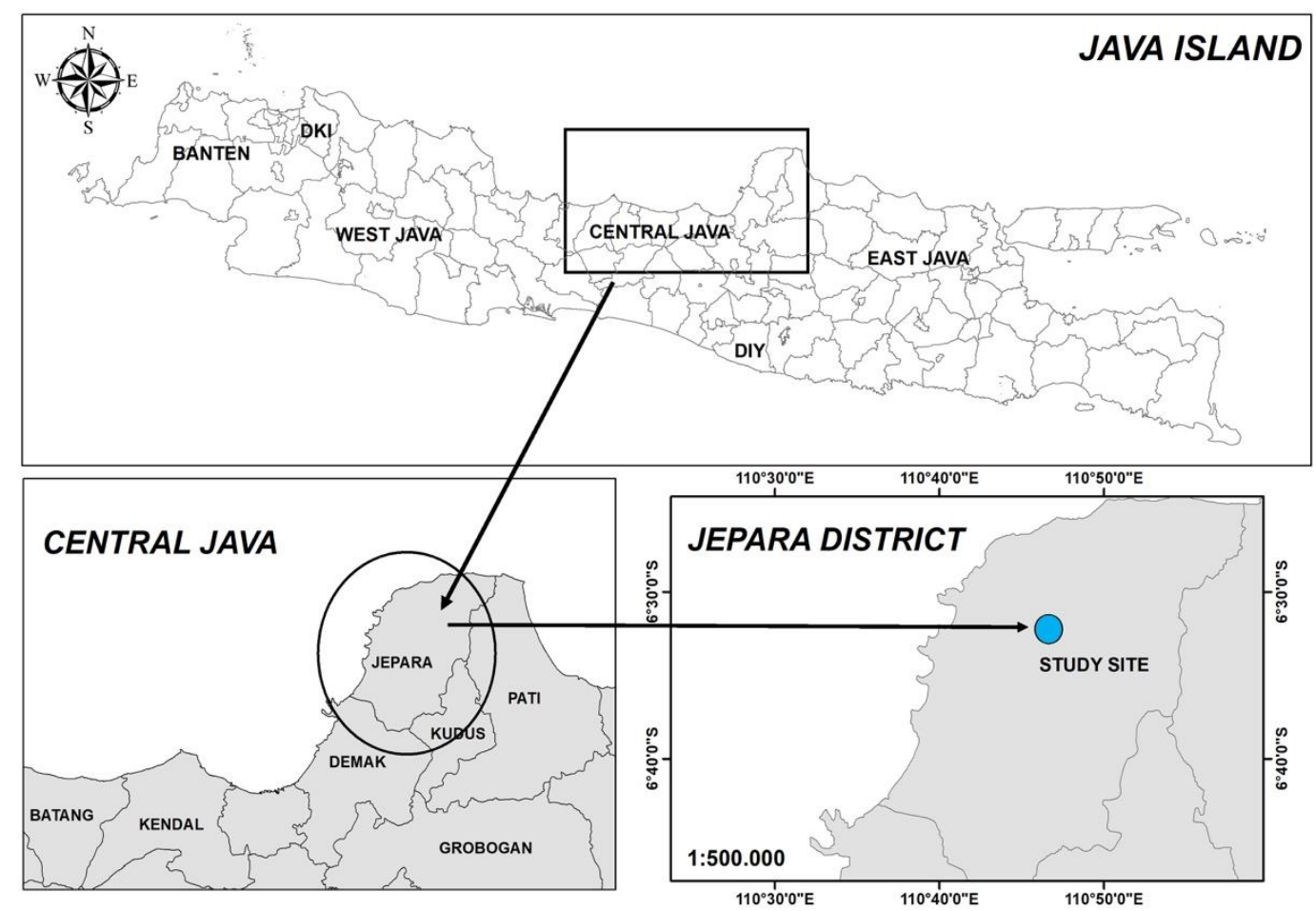

Figure 1. Study area of planting trial of eucalyptus in Jepara District (blue symbol).

Each species was planted in a square plot of 0.1 ha comprising 100 measured trees and 44 border trees (Figure 2 ). The main function of border trees was to indicate the clear boundaries among treatments in every block. Moreover, to support the activity of monitoring, a nameplate was placed in each treatment plot using a specific code. Every measured tree was also marked by individual identity number.

This trial was established in August 2020. Site preparation was conducted to identify the variation of environmental gradient before determining the layout of experimental design. It was required to create a homogeneous condition in each block to minimize the influence of environmental gradient on treatment plots (Gonçalves et al. 2010). The site preparation consisted of several stages, including measuring slope variation, observing waterlog, identifying wind disturbance, and assessing soil quality (Wirabuana et al. 2020a). Soil quality assessment was conducted by collecting soil samples in five different points at three depth layers of 0 $10 \mathrm{~cm}, 11-20 \mathrm{~cm}$, and 21-30 cm (Li et al. 2018; Wirabuana et al. 2019; Sadono et al. 2021b) (Figure 3). Then, the samples were packed and brought to the laboratory for quantifying their characteristics, namely soil acidity, soil organic carbon, total nitrogen, available phosphorus, total potassium, and cation exchange capacity (Table 1). Soil acidity was measured using $\mathrm{pH}$ meter. The quantification of soil organic carbon was conducted using Walkey and Black method. Total nitrogen was estimated by Kjeldahl method. The analysis of available phosphorus was executed using Olsen method. The method of flame photometry was utilized to calculate the total potassium. The use of ammonium acetate method was applied to quantify the content of cation exchange capacity. The protocol of soil analysis was conducted referring to the guide for methods of soil, plant, and water analysis published by Estefan et al. (2013).

The plant materials of E. alba, E. urophylla, and $E$. pellita used in this study were obtained from different provenance sources since every species has different natural distribution. E. alba and E. urophylla were from provenance Timor, East Nusa Tenggara, while E. pellita was from provenance Muting, Papua. The seeds of such species were sown in the nursery for 90 days. In parallel, soil tillage was conducted to improve soil structure two weeks before field planting. A week before planting the seedlings, grading activity was undertaken to determine the quality of seedlings from each species. In this case, only seedlings with a height of $30 \mathrm{~cm}$ and healthy conditions were used as plant materials for planting. Seedlings were planted by initial spacing of $3 \mathrm{~m} \times 3 \mathrm{~m}$. Fertilizer NPK with concentration of 15:15:15 was also added to each seedling with a dose of $100 \mathrm{~g}$ to increase the availability of nutrients for eucalyptus because the site experiment had a low content of nitrogen, phosphorus, and potassium in the soil. Moreover, several studies reported eucalyptus is highly responsive to phosphorus availability since it was a macronutrient exceptionally required by this plant (Amezquita et al. 2018; Bassaco et al. 2018; Sadono et al. 2021b). To support the early growth of eucalyptus, the application of weed control was also implemented by slashing and chemical spraying at three and six months after planting. 


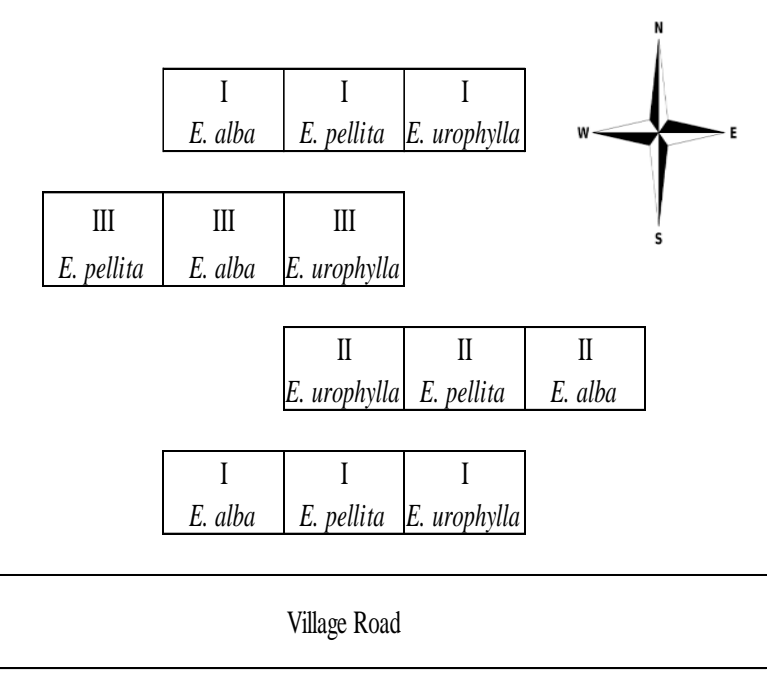

A

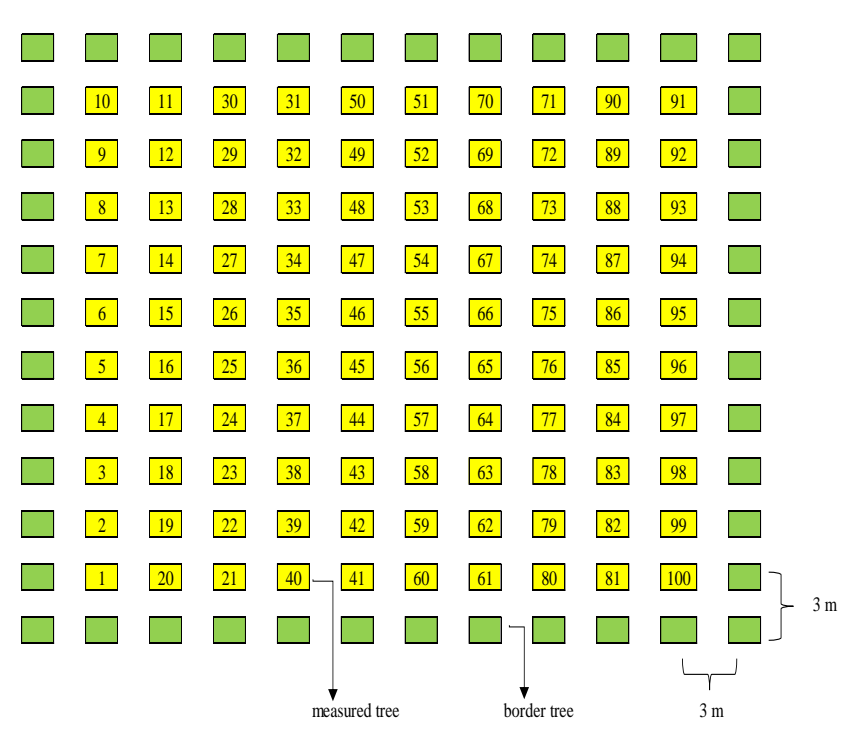

B

Figure 2. The layout of experimental design in the study area for evaluating the performance of eucalyptus stand of three different species established in Jepara District, Central Java, Indonesia. A. The position of every treatment in each block, and B. The position of measured and border trees in every treatment plot

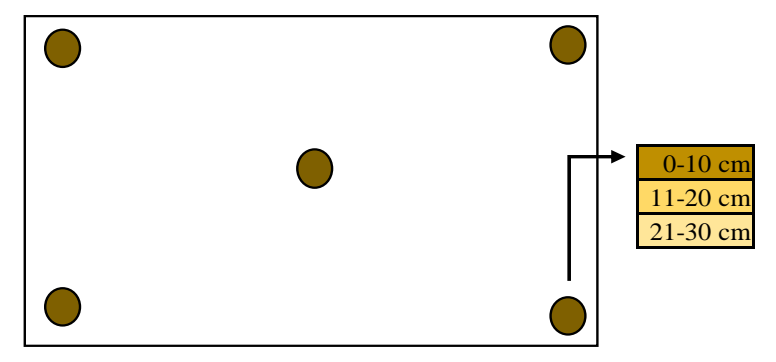

Figure 3. The distribution of five sample points for collecting soil sample in the site experiment (brown circle)

\section{Data collection}

Data were collected at 6 months after planting. This period was frequently used by most plantation forests company in Indonesia to conduct the first evaluation of planting trials (Wirabuana et al. 2019). The period was a critical moment to assess the adaptability of species to environmental conditions outside their natural habitat (Stuepp et al. 2020). The process of data collection was conducted from March to April 2021, consisting of several activities, i.e., stand measurement, destructive sampling, and laboratory analysis. Sixteen parameters were selected to evaluate the performance of the three eucalyptus species, including survival rate, height, diameter, biomass production (stem, branches, foliage, and total aboveground), crown length, crown radius, crown projection area, crown ration, individual leaf area, individual leaf dry weight, specific leaf area, leaf mass area, and leaf area index.

Survival rate was defined as the ratio of actual density and initial planting density. Height was measured from aboveground to top crown using a measuring pole
(Halomoan et al. 2015). Diameter was measured at $0.3 \mathrm{~m}$ aboveground by a caliper (Wirabuana et al. 2019). The crown length was quantified from crown base to top crown while crown ratio was calculated as the ratio between crown length and tree height. Crown radius was computed as the quadratic mean crown radius at eight directions (eq.1) (Wirabuana et al. 2019). The transition from crown radius to crown projection area was determined by the occupation area of every tree (eq.2) (Pretzsch et al. 2015).

$$
\begin{aligned}
& \mathrm{CR}=\left(\left(\mathrm{R}_{\mathrm{N}}^{2}+\mathrm{R}_{\mathrm{NE}}^{2}+\ldots+\mathrm{R}_{\mathrm{NW}}{ }^{2}\right) / 8\right)^{1 / 2} \\
& \mathrm{CPA}=\pi \mathrm{x} \mathrm{CR}^{2}
\end{aligned}
$$

Wherein: CR was a quadratic mean crown radius of every tree $(\mathrm{m}), \mathrm{R}$ represented crown radius in certain direction $(\mathrm{m})$, and CPA described crown projection area of each tree $\left(\mathrm{m}^{2}\right)$.

To quantify biomass accumulation and leaf characteristics of each species, destructive sampling was conducted step by step in a chronological manner. Each species was represented by five sample trees. Those sample trees were determined by considering the distribution of diameter to obtain the balance growth dimension from small to big trees (Sadono et al. 2021a). In this study, the diameter was classified into three classes, including small $(1.0-1.9 \mathrm{~cm})$, medium $(2.0-2.9 \mathrm{~cm})$, and big $(3.0-3.9 \mathrm{~cm})$. After the sample tree was felled, the tree component was separated into stem, branches, and foliage. For part of foliage, the sample was also stratified into three layers based on leaves position, i.e., base, middle, and top. It was conducted to facilitate the measurement of leaf characteristics. From every layer, ten leaf samples were taken randomly. Thereby, the number of samples for determining leaf attributes in each sample tree was 30 samples. 
Table 1. Soil characteristics at the research site. Data are presented in mean \pm standard deviation

\begin{tabular}{lcccc}
\hline \multicolumn{1}{c}{ Soil parameter } & Symbol & Units & Value & Categories \\
\hline Soil acidity & $\mathrm{pH}$ & - & $6.00 \pm 0.86$ & Slightly acid \\
Soil organic carbon & $\mathrm{SOC}$ & $\%$ & $2.97 \pm 0.37$ & Moderate \\
Total nitrogen & $\mathrm{N}-$ tot & $\%$ & $0.17 \pm 0.01$ & Low \\
Available phosphorus & $\mathrm{Av}-\mathrm{P}$ & $\mathrm{ppm}$ & $2.79 \pm 1.54$ & Very low \\
Total potassium & $\mathrm{K}-\mathrm{tot}$ & $\mathrm{cmolc} \mathrm{kg}$ & $0.21 \pm 0.12$ & Very low \\
Cation exchange capacity & $\mathrm{CEC}$ & $\mathrm{cmolc} \mathrm{kg}^{-1}$ & $10.11 \pm 3.14$ & Low \\
\hline
\end{tabular}

Note: the classification of soil quality was determined following the soil quality categories reported by (Nandini and Narendra 2017)

The fresh weight of each component was measured in the field using a hanging balance. Afterward, approximately $500 \mathrm{~g}$ subsample from each part was taken and brought to the laboratory for dried. Before starting the drying process, the area of selected leaf samples was measured using a planimeter. Then, the subsample of each component (including the selected leaf samples) was dried using an oven for 48 hours at $70^{\circ} \mathrm{C}$ before measuring their dry weight (Hakamada et al. 2017). The biomass accumulation in each component was calculated by multiplying the ratio of dry-fresh weight from subsample with the total fresh weight of each part from field measurement (eq.3) (Altanzagas et al. 2019) while total aboveground biomass for each individual tree was calculated by summing the biomass distribution in stem, branches, and foliage (eq.4) (Rance et al. 2017).

$$
\begin{aligned}
& \mathrm{W}_{\mathrm{c}}=\left(\mathrm{DW}_{\mathrm{s}} / \mathrm{FW}_{\mathrm{s}}\right) \times \mathrm{FW}_{\mathrm{c}} \\
& \mathrm{W}_{\mathrm{t}}=\mathrm{W}_{\text {stem }}+\mathrm{W}_{\text {branches }}+\mathrm{W}_{\text {foliage }}
\end{aligned}
$$

Wherein: $W_{c}$ was biomass from every tree component like stem, branches, or foliage $(\mathrm{kg}), D W_{s}$ described the dry weight of subsample $(\mathrm{kg}), F W_{s}$ indicated the fresh weight of sub-sample $(\mathrm{kg}), F W_{c}$ was the total fresh weight of tree component $(\mathrm{kg})$, and $W_{t}$ signified total aboveground biomass of individual tree $(\mathrm{kg})$. Then, the result of destructive sampling was converted to estimate the biomass production of eucalyptus stand from every species in treatment plots.

To measure the leaf characteristics, the dry weight of each selected leaf sample was determined using a digital analytic scale. The specific leaf area was calculated based on the ratio of leaf area and leaf dry weight (eq.5) (Hakamada et al. 2016). In opposite condition, leaf mass area was computed by dividing leaf dry weight and leaf area (eq.6) (De La Riva et al. 2016). Leaf area index from each sample tree was quantified following this equation (eq. 7) (Wirabuana et al. 2019).

$$
\begin{aligned}
& \mathrm{SLA}=\mathrm{LA} / \mathrm{LW} \\
& \mathrm{LMA}=\mathrm{LW} / \mathrm{LA} \\
& \mathrm{LAI}=\left(\mathrm{W}_{\text {foliage }} \mathrm{X} \mathrm{SLA}\right) / \mathrm{CPA}
\end{aligned}
$$

Wherein: $S L A$ was specific leaf area $\left(\mathrm{m}^{2} \mathrm{~kg}^{-1}\right), L M A$ represented leaf mass area $\left(\mathrm{kg} \mathrm{m}^{-2}\right), L A$ described individual leaf area $\left(\mathrm{cm}^{2}\right), L W$ was individual leaf dry weight $(\mathrm{g})$, and $L A I$ indicated leaf area index.

\section{Data analysis}

Statistical analysis was processed using software $\mathrm{R}$ version 4.0 .2 with a significant level of $5 \%$. The package agricolae was used to facilitate the process of data analysis. Descriptive test was applied to identify the data characteristics, primarily related to minimum, maximum, mean, standard deviation, and coefficient of variation. It aimed to assess the accuracy and precision of data collected from stand measurement, destructive sampling, and laboratory analysis. The normality of data was evaluated using Shapiro-Wilk test. Homogeneity variance among treatments was examined using Bartlett's test. The comparison means eucalyptus performance among three species for each parameter was tested using ANOVA followed by HSD Tukey. The analysis of correlation using a pallet matrix was also done to evaluate the relationship between observed parameters.

\section{RESULTS AND DISCUSSION}

\section{Growth performance}

The survival rate among species did not significantly differ ( $p>0.05$ ) (Table 2). Each species had a survival rate of more than $80 \%$, indicating that every species had a good tolerance to the environmental condition in the study area. The highest survival rate was recorded in $E$. alba (90.4 $\pm 2.19 \%)$, followed by E. pellita $(89.6 \pm 3.57 \%)$ and $E$. urophylla $(88.8 \pm 5.21 \%)$. In the context of plantation forest management, survival is an essential indicator to evaluate the species performance since it determines the number of trees that could be harvested at the end of the rotation (Truax et al. 2018). This parameter also directly affects land cover and tree competition at the stand level (Kweon \& Comeau 2019). Moreover, plant survival also has a strong relationship to the efficiency of planting cost for establishing plantation forests. The development of a species in plantation forest requires a high survival to obtain optimum stand productivity because it becomes a multiplier factor to estimate the wood volume and biomass production in hectare units. 
Table 2. The comparison of the growth, aboveground biomass, crown development, and leaf characteristics of three different eucalyptus species trialed in Jepara District, Central Java, Indonesia. Data are presented in mean \pm standard deviation

\begin{tabular}{|c|c|c|c|c|c|c|}
\hline \multirow{2}{*}{ Group variable } & \multirow{2}{*}{ Measured parameter } & \multirow{2}{*}{ Unit } & \multicolumn{3}{|c|}{ Species } & \multirow{2}{*}{ p-value } \\
\hline & & & E. alba & E. pellita & E. urophylla & \\
\hline \multirow[t]{3}{*}{ Growth } & Survival & $\%$ & $90.4 \pm 2.19 a$ & $89.6 \pm 3.57 a$ & $88.8 \pm 5.21 \mathrm{a}$ & $0.958^{\text {ns }}$ \\
\hline & Height & $\mathrm{m}$ & $2.82 \pm 0.25 \mathrm{a}$ & $3.00 \pm 0.21 \mathrm{a}$ & $1.87 \pm 0.29 b$ & $<0.001^{*}$ \\
\hline & Diameter & $\mathrm{cm}$ & $2.31 \pm 0.19 \mathrm{a}$ & $2.39 \pm 0.19 \mathrm{a}$ & $1.62 \pm 0.15 b$ & $<0.001^{*}$ \\
\hline \multirow[t]{4}{*}{ Aboveground biomass } & Stem biomass & $\mathrm{kg} \mathrm{ha}^{-1}$ & $16.58 \pm 2.75 \mathrm{ab}$ & $17.25 \pm 3.12 \mathrm{a}$ & $12.01 \pm 2.56 \mathrm{~b}$ & $0.024^{*}$ \\
\hline & Branches biomass & $\mathrm{kg} \mathrm{ha}^{-1}$ & $11.15 \pm 1.90 \mathrm{a}$ & $12.10 \pm 1.91 \mathrm{a}$ & $6.78 \pm 1.11 \mathrm{~b}$ & $<0.001^{*}$ \\
\hline & Foliage biomass & $\mathrm{kg} \mathrm{ha}^{-1}$ & $21.40 \pm 2.24 \mathrm{a}$ & $20.50 \pm 2.40 \mathrm{a}$ & $24.16 \pm 2.33 \mathrm{a}$ & $0.069^{\text {ns }}$ \\
\hline & Total Aboveground biomass & $\mathrm{kg} \mathrm{ha}^{-1}$ & $49.14 \pm 2.80 \mathrm{a}$ & $49.86 \pm 3.60 \mathrm{a}$ & $42.96 \pm 3.30 \mathrm{~b}$ & $0.010^{*}$ \\
\hline \multirow[t]{4}{*}{ Crown development } & Crown radius & $\mathrm{m}$ & $0.86 \pm 0.05 \mathrm{a}$ & $0.90 \pm 0.04 \mathrm{a}$ & $0.64 \pm 0.06 \mathrm{~b}$ & $<0.001^{*}$ \\
\hline & Crown length & M & $2.15 \pm 0.16 \mathrm{a}$ & $2.27 \pm 0.14 \mathrm{a}$ & $1.52 \pm 0.19 b$ & $<0.001^{*}$ \\
\hline & Crown projection area & $\mathrm{m}^{2}$ & $2.47 \pm 0.29 \mathrm{a}$ & $2.68 \pm 0.27 \mathrm{a}$ & $1.42 \pm 0.28 b$ & $<0.001^{*}$ \\
\hline & Crown ratio & - & $0.93 \pm 0.02 \mathrm{a}$ & $0.95 \pm 0.04 \mathrm{a}$ & $0.93 \pm 0.04 \mathrm{a}$ & $0.763^{\text {ns }}$ \\
\hline \multirow[t]{5}{*}{ Leaf characteristics } & Individual Leaf area & $\mathrm{cm}^{2}$ & $64.27 \pm 2.91 b$ & $63.30 \pm 3.67 \mathrm{~b}$ & $78.52 \pm 8.66 \mathrm{a}$ & $0.001^{*}$ \\
\hline & Individual Leaf dry weight & $\mathrm{g}$ & $0.80 \pm 0.02 \mathrm{~b}$ & $0.79 \pm 0.04 b$ & $0.92 \pm 0.08 \mathrm{a}$ & $0.007^{*}$ \\
\hline & Specific leaf area & $\mathrm{m}^{2} \mathrm{~kg}^{-1}$ & $7.93 \pm 0.13 b$ & $7.91 \pm 0.17 b$ & $8.41 \pm 0.14 \mathrm{a}$ & $<0.001^{*}$ \\
\hline & Leaf mass area & $\mathrm{kg} \mathrm{m}^{-2}$ & $0.12 \pm 0.002 \mathrm{a}$ & $0.12 \pm 0.002 \mathrm{a}$ & $0.11 \pm 0.002 b$ & $<0.001^{*}$ \\
\hline & Leaf area index & - & $5.39 \pm 0.52 \mathrm{a}$ & $5.76 \pm 0.44 \mathrm{a}$ & $3.40 \pm 0.61 \mathrm{~b}$ & $<0.001^{*}$ \\
\hline
\end{tabular}

Note: the symbol * indicated a significant difference among species based on ANOVA test while the symbol ${ }^{\text {ns }}$ showed a non-significant difference among species referring to ANOVA test. A similar letter in row indicates the parameter between species is not significantly different according to HSD Tukey test

Even though the survival rate was not significantly different among species, this study found there was a significant difference in height and diameter growth from the three eucalyptus species $(\mathrm{p}<0.05)$ (Table 2$)$. E. pellita showed higher height and diameter than those of $E$. alba and E. urophylla. This finding verified the land characteristics in the study site are more suitable to $E$. pellita than other species. It is also supported by the previous studies explains that E. pellita is a species naturally distributed in the lowland area with a range altitude of 0-700 $\mathrm{m}$ above sea level (Hung et al. 2015). This species prefers a soil acidity in the range of 5.0-6.0 (Harwood et al. 1997). According to the site description, the study area is classified as a lowland area because it has an altitude of $70 \mathrm{~m}$ above sea level. Moreover, the soil acidity of study area is also categorized into slightly acid with $\mathrm{pH}$ of $6.00 \pm 0.86$ (Table 1). The biophysical conditions at the study site principally support the site requirement for E. pellita development.

\section{Biomass accumulation}

Biomass production from the three species relatively varied (Table 2). Our study recorded the accumulation of biomass in stem, branches, and total aboveground differed significantly $(\mathrm{p}<0.05)$. In contrast, the biomass distribution in the foliage component was not significantly different $(\mathrm{p}>0.05)$. The greatest total aboveground biomass was observed in E. pellita $\left(49.86 \pm 3.60 \mathrm{~kg} \mathrm{ha}^{-1}\right)$, followed by $E$. alba $\left(49.14 \pm 2.80 \mathrm{~kg} \mathrm{ha}^{-1}\right)$, and E. urophylla $(42.96 \pm 3.30 \mathrm{~kg}$ $\left.\mathrm{ha}^{-1}\right)$. A similar pattern was also found in stem and branch biomass. Interestingly, E. pellita had a lower accumulation of foliage biomass $\left(20.50 \pm 2.40 \mathrm{~kg} \mathrm{ha}^{-1}\right)$ than E. alba $\left(21.40 \pm 2.24 \mathrm{~kg} \mathrm{ha}^{-1}\right)$ and E. urophylla $\left(24.16 \pm 2.33 \mathrm{~kg} \mathrm{ha}^{-1}\right)$. It was caused by the lower value of leaf area and leaf dry weight in this species (Table 2).

This study found that the largest biomass distribution for all species at 6 months after field planting was observed in the foliage (41-56\%), followed by stem (28-34\%) and branches (16-24\%) (Table 3). In general, the biomass allocation in each tree component among the three species differed significantly (Figure 4). However, the relative contribution of stem biomass to total biomass among the three species was statistically equal. In contrast, the percentage contribution of foliage and branches biomass to total biomass was highly different among those species. Surprisingly, our study also demonstrated that biomass proportion in stem and branches gradually improved along with the increasing of diameter classes while the distribution of biomass in foliage progressively declined with the increment of diameter classes.

The biomass allocation within tree is principally affected by its physiological process (Poorter et al. 2012). At the early growth periods, trees generally accumulate more biomass to foliage to accelerate photosynthesis process (Kohl et al. 2017). When the trees become bigger and older, the accumulation of foliage biomass slowly declines since trees provide more photosynthate to stem to improve growth and accelerate translocation process (Dong et al. 2018, Altanzagas et al. 2019, Wirabuana et al. 2020b). Moreover, the occurrence of leaves shedding by trees also reduces the biomass accumulation in foliage. Some previous studies reported the leaves shedding occurs more intensively with the increasing tree competition, drought stress, and age of tree (Gutiérrez-Soto et al. 2008, Xie et al. 2015, Nguyen et al. 2019). 
Table 3. Ratio of the biomass of stem, branches, and foliage to the total aboveground biomass from sample tree. Data are presented in mean, standard deviation, and range

\begin{tabular}{|c|c|c|c|c|c|c|c|c|c|}
\hline \multirow{2}{*}{ Species } & \multicolumn{3}{|c|}{ Stem biomass/AGB } & \multicolumn{3}{|c|}{ Branches biomass/AGB } & \multicolumn{3}{|c|}{ Foliage biomass/AGB } \\
\hline & Mean & SD & Range & Mean & SD & Range & Mean & SD & Range \\
\hline E. alba & 0.34 & 0.04 & $0.28-0.38$ & 0.23 & 0.03 & $0.18-0.25$ & 0.44 & 0.07 & $0.37-0.54$ \\
\hline E. pellita & 0.34 & 0.04 & $0.30-0.40$ & 0.24 & 0.02 & $0.21-0.28$ & 0.41 & 0.07 & $0.33-0.49$ \\
\hline E. urophylla & 0.28 & 0.04 & $0.25-0.33$ & 0.16 & 0.02 & $0.13-0.19$ & 0.56 & 0.06 & $0.50-0.62$ \\
\hline Total & 0.32 & 0.05 & $0.25-0.40$ & 0.21 & 0.04 & $0.13-0.28$ & 0.47 & 0.09 & $0.33-0.62$ \\
\hline
\end{tabular}

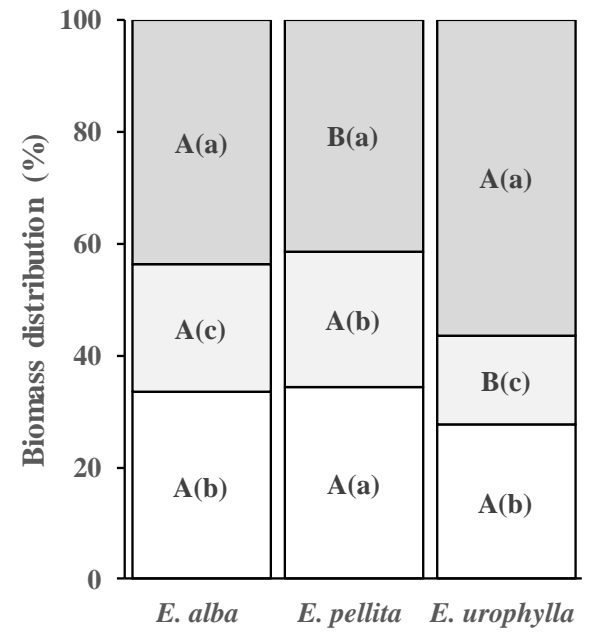

A

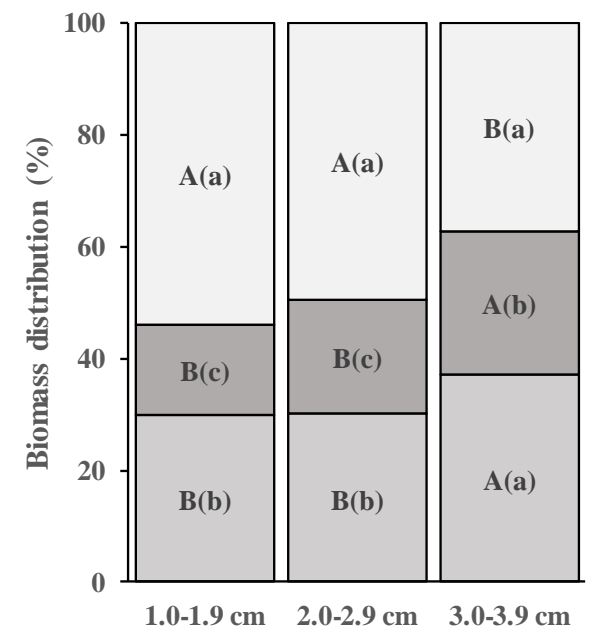

B

Figure 4. A. Comparison of biomass distribution in each tree component among the three eucalyptus species; B. Relative contribution of biomass in each tree component to total aboveground biomass across diameter classes. A similar big letter demonstrated there was not significant difference in biomass accumulation in the same component at different species and diameter classes. A similar small letter indicated that there was not a significant difference in biomass proportion among tree components at the same species and diameter classes.

Biomass is an attribute of tree that has an important role in biogeochemical cycle (Houghton et al. 2009). Higher biomass indicates greater carbon storage since around $50 \%$ of biomass is composed of carbon (Latifah et al. 2018, Viera \& Rodríguez-Soalleiro 2019, Wirabuana et al. 2020a). Moreover, biomass is also a source of nutrients to maintain soil fertility. In this case, when litter is decomposed, some amounts of nutrients would be returned to soil. In fact, majority of plantation forests in other countries have utilized the biomass residue from harvesting activities as an additional fertilizer to minimize the fertilization cost (Versini et al. 2014, Ferreira et al. 2016, Van Bich et al. 2019).

Besides having a lot of benefits related to ecological functions, biomass is also used as a measurement unit to determine the commercial value of wood, mainly in the pulp and paper, fuelwood, and pellets industries (Visser et al. 2020). However, the commercial value of biomass is only applied for stem components because it is the primary product of woody species like eucalyptus. Referring to the results, E. pellita showed higher potential stem biomass $\left(17.25 \pm 3.12 \mathrm{~kg} \mathrm{ha}^{-1}\right)$ than E. alba $\left(16.58 \pm 2.75 \mathrm{~kg} \mathrm{ha}^{-1}\right)$ and E. urophylla $\left(12.01 \pm 2.56 \mathrm{~kg} \mathrm{ha}^{-1}\right)($ Table 2$)$.

\section{Crown development}

Crown characteristics among the three species were significantly different for all parameters except in crown ratio (Table 4). The largest average crown projection area was observed in E. pellita $\left(2.68 \pm 0.27 \mathrm{~m}^{2}\right)$, followed by $E$. alba $\left(2.47 \pm 0.29 \mathrm{~m}^{2}\right)$ and E. urophylla $\left(1.42 \pm 0.28 \mathrm{~m}^{2}\right)$. Greater crown dimension commonly indicates more biomass production because crown is the main tree component that plays an important role in photosynthesis process (Binkley et al. 2013). It was also strengthened by the results of correlation analysis that there was a strong correlation between crown radius, crown length, and crown projection area with total aboveground biomass of eucalyptus species (Figure 6). Trees with a big dimension of crown commonly have better growth performance than trees with a small crown size. It was also confirmed by the study results wherein the size of crown dimension significantly improved along with the increasing diameter class (Figure 5). 


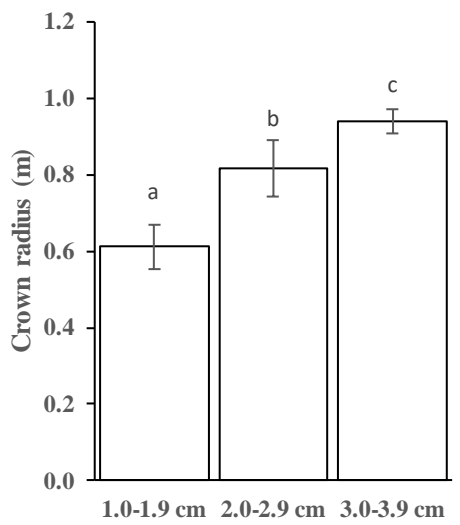

A

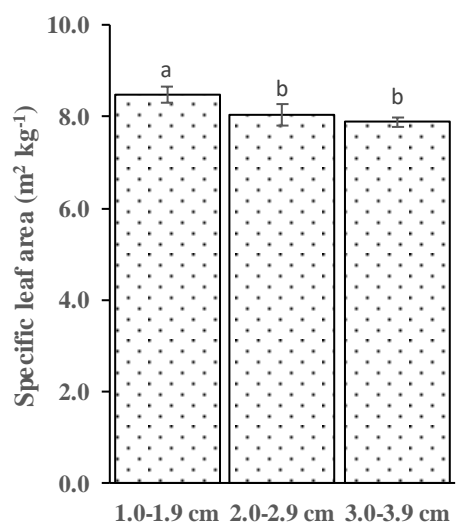

D

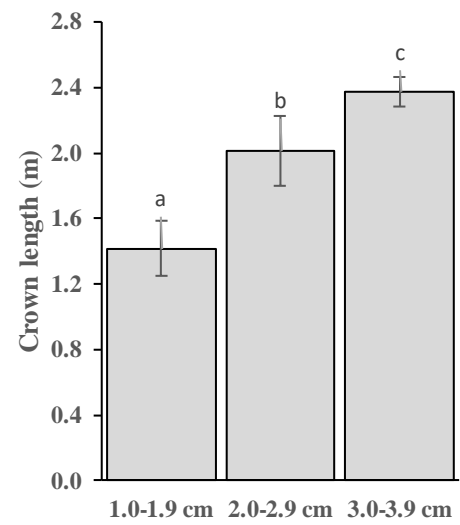

B

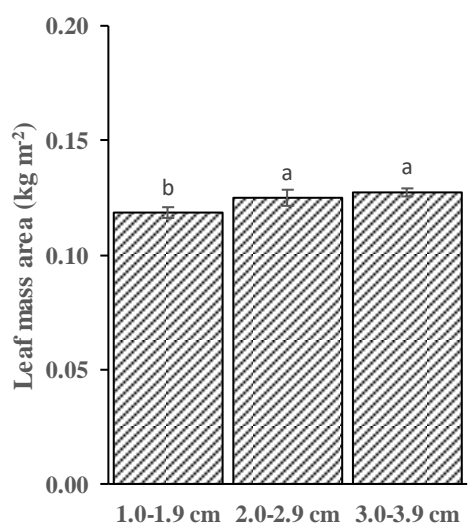

$\mathbf{E}$

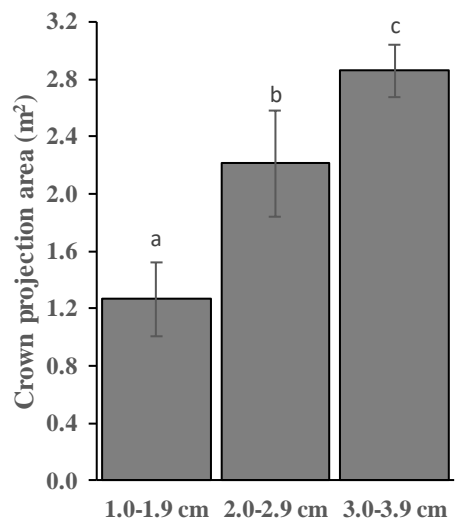

C

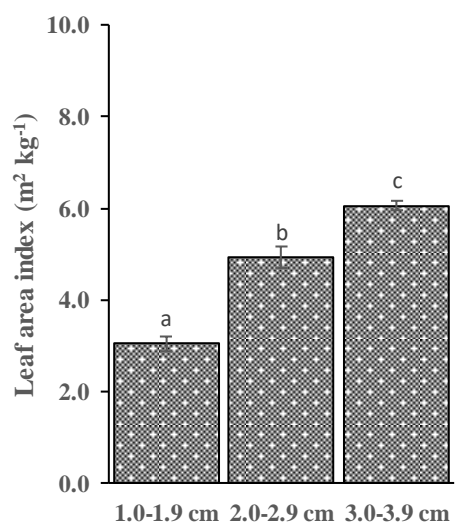

$\mathbf{F}$

Figure 5. Crown development and leaf characteristics of eucalyptus species across diameter classes. A. Crown radius; B. Crown length; C. Crown projection area; D. Specific leaf area; E. Leaf mass area; and F. Leaf area index. Data are presented in trend for all species.

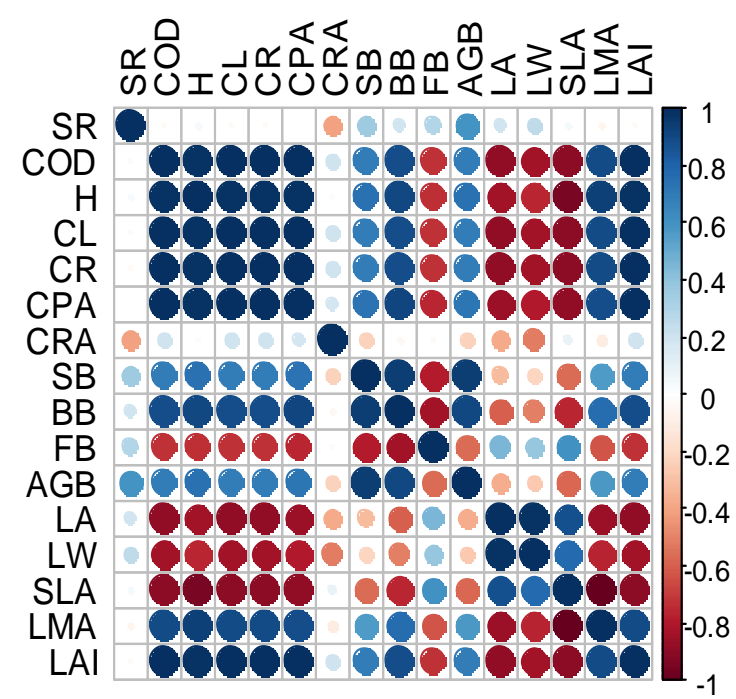

Figure 6. A pallete diagram demonstrating the correlations among measured parameters. SR (survival); COD (diameter); H (height); CL (crown length); CR (crown radius); CPA (crown projection area); CRA (crown ratio); $\mathrm{SB}$ (stem biomass); BB (branches biomass); FB (foliage biomass); AGB (total aboveground biomass); LA (individual leaf area); LW (individual leaf dry weight); SLA (specific leaf area); LMA (leaf mass area); LAI (leaf area index).
The development of crown dimensions in every tree is commonly affected by environmental conditions, primarily related to site quality and space availability. A study reported the size of crown dimension is relatively bigger at good sites than poor sites (DeRose and Seymour 2009). Meanwhile, larger space availability would stimulate better crown development since the growth of the crown is highly responsive to the growing space (Pretzsch et al. 2015). The information about crown development is also important to identify the level of tree competition because it is necessary as a basic consideration to formulate the best silviculture treatment, such as thinning and pruning (McTague \& Weiskittel 2016). In this study, the site quality and space availability of every species were principally equal since each species was planted by spacing $3 \mathrm{~m} \times 3 \mathrm{~m}$. Therefore, the dimension of crown from three species was naturally affected by its suitability to the site characteristics. At the end of 6 months after planting, E. pellita showed better crown dimension than other species (Table 2).

\section{Leaf characteristics}

Leaf characteristics from the three species significantly differed for all parameters $(\mathrm{p}<0.05)$ (Table 2). E. urophylla showed greater average individual leaf area, individual leaf dry weight, and specific leaf area than other species. 
Nevertheless, the highest mean leaf area index (LAI) was found in E. pellita $(5.76 \pm 0.44)$, followed by $E$. alba $(5.39 \pm 0.52)$ and E. urophylla $(3.40 \pm 0.61)$. LAI is an important parameter to describe the effectiveness of nutrients absorption and photosynthesis (Bréda 2008). This parameter is generally used as one of the criteria to evaluate the application of silviculture treatment in plantation forests primarily related to fertilization and spacing management (Laclau et al. 2009, Forrester et al. 2012, Van Bich et al. 2019). Higher LAI generates better growth performance and greater biomass since the nutrients uptake and photosynthesis occurred more optimum. It explains the primary reason why E. pellita resulted in a greater average of tree dimensions and bigger total biomass than those of E. alba and E. urophylla.

Based on the results, the value of LAI and leaf mass area significantly increased with the increment of diameter classes (Figure 6). A different trend was noted in specific leaf areas in which this parameter gradually declined with the increase of diameter classes. The specific leaf area in each species relatively varies depending on its adaptability to the environment (Rosbakh et al. 2015). The previous studies reported that the specific leaf area would decline along with the bigger tree dimension because it has a negative correlation to the age of tree (Xiao et al. 2006, Karavin 2013, Dwyer et al. 2014). Bigger tree dimension indicates an older tree. However, this trend is not commonly discovered in every species due to the impact of several factors, such as seasonal variation, tree competition, and maintenance activities (Zhu et al. 2016).

Finally, this study concluded that in general, the performance of E. pellita at the initial period of planting in Jepara was substantially superior to $E$. alba and $E$. urophylla since it demonstrated the highest mean in diameter, height, total biomass, and leaf area index at the 6 months after field establishment. However, continuous evaluation is still required to monitor the consistent performance of three species in the site experiment.

\section{ACKNOWLEDGEMENTS}

The authors deliver our gratitude to farmers who provided land for supporting this research. We are also very grateful to reviewers for suggestions to improve this article.

\section{REFERENCES}

Acuña E, Cancino J, Rubilar R, Sandoval S. 2018. Aboveground biomass growth and yield of first rotation cutting cycle of Acacia and Eucalyptus short-rotation dendroenergy crops. Revista Árvore 41: 110. DOI: $10.1590 / 1806-90882017000600008$.

Aggangan NS, Moon HK, Han SH. 2013. Growth and nutrient accumulation of Eucalyptus pellita F. Muell. in response to inoculation with edible ectomycorrhizal mushrooms. Asia Life Sci 22: 95-112.

Aguilos R, Marquez C, Adornado H, Aguilos M. 2020. Domesticating commercially important native tree species in the Philippines: Early growth performance level. Forests 11 (8): 885 DOI: 10.3390/f11080885.
Altanzagas B, Luo Y, Altansukh B, Dorjsuren C, Fang J, Hu H. 2019. Allometric equations for estimating the above-ground biomass of five forest tree species in Khangai, Mongolia. Forests 10 (8): 661. DOI: 10.3390/f10080661

Amezquita PSM, Rubiano JAM, Filho NFDB, Cipriani HN. 2018. Fertilization effects on Eucalyptus pellita F. Muell productivity in the Colombian Orinoco Region. Revista Arvore 42: 1-8. DOI: 10.1590/1806-9088201800050002.

Barreiro S, Tomé M. 2012. Analysis of the impact of the use of eucalyptus biomass for energy on wood availability for eucalyptus forest in Portugal: A simulation study. Ecol Soc 17 (2): 14. DOI: 10.5751/ES04642-170214.

Bassaco MVM, Motta ACV, Pauletti V, Prior SA, Nisgoski S, Ferreira CF. 2018. Nitrogen, phosphorus, and potassium requirements for Eucalyptus urograndis plantations in southern Brazil. New Forests 49: 681-697. DOI: 10.1007/s11056-018-9658-0.

Binkley D, Campoe OC, Gspaltl M, Forrester DI. 2013. Light absorption and use efficiency in forests: Why patterns differ for trees and stands. Forest Ecol Manag 288: 5-13. DOI: 10.1016/j.foreco.2011.11.002.

Bréda NJJ. 2008. Leaf area index. In: Encyclopedia of Ecology. DOI: 10.1016/B978-0-444-63768-0.00849-0.

Cavalett O, Slettmo SN, Cherubini F. 2018. Energy and environmental aspects of using Eucalyptus from Brazil for energy and transportation services in Europe. Sustainability 10 (11): 4068. DOI: 10.3390/su10114068.

De La Riva EG, Olmo M, Poorter H, Ubera JL, Villar R. 2016. Leaf mass per area (LMA) and its relationship with leaf structure and anatomy in 34 Mediterranean woody species along a water availability gradient. PLoS One 11 (2): e0148788. DOI: 10.1371/journal.pone.0148788.

DeRose RJ, Seymour RS. 2009. The effect of site quality on growth efficiency of upper crown class Picea rubens and Abies balsamea in Maine, USA. Can J For Res 39: 777-784. DOI: 10.1139/X09-012.

Dong L, Zhang L, Li F. 2018. Additive biomass equations based on different dendrometric variables for two dominant species (Larix gmelini Rupr. and Betula platyphylla Suk.) in natural forests in the Eastern Daxing'an Mountains, Northeast China. Forests 9 (5): 261. DOI: 10.3390/f9050261.

Dwyer JM, Hobbs RJ, Mayfield MM. 2014. Specific leaf area responses to environmental gradients through space and time. Ecology 95: 399410. DOI: $10.1890 / 13-0412.1$.

Estefan G, Sommer R, Ryan J. 2013. Methods of soil, plant, and water analysis. International Center for Agriculture Research in the Dry Areas. Retrieved from https://www.gob.mx/siap/articulos/cierreestadistico-de-la-produccion-ganadera-2017?idiom=es

Ferreira GWD, Soares EMB, Oliveira FCC, Silva IR, Dungait JAJ, Souza IF, Vergütz L. 2016. Nutrient release from decomposing eucalyptus harvest residues following simulated management practices in multiple sites in Brazil. For Ecol Manag 370: 1-11. DOI: 10.1016/j.foreco.2016.03.047.

Ferreira MC, Santos RC dos, Castro RVO, Carneiro A de CO, Silva GGC da, Castro AFNM, Costa SE de L, Pimenta AS. 2017. Biomass and energy production at short rotation eucalyptus clonal plantations deployed in Rio Grande Do Norte1. Revista Árvore 41: 1-7. DOI: 10.1590/1806-90882017000500004

Forrester DI. 2013. Growth responses to thinning, pruning and fertiliser application in Eucalyptus plantations: A review of their production ecology and interactions. For Ecol Manag 310: 336-347. DOI: 10.1016/j.foreco.2013.08.047.

Forrester DI, Collopy JJ, Beadle CL, Baker TG. 2012. Interactive effects of simultaneously applied thinning, pruning and fertiliser application treatments on growth, biomass production and crown architecture in a young Eucalyptus nitens plantation. For Ecol Manage 267: 104-116. DOI: 10.1016/j.foreco.2011.11.039.

Gonçalves JLM, Wichert MCP, Gava JL, Masetto A V, Junior AJC, Serrano MIP, Mello SLM. 2010. Soil fertility and growth of Eucalyptus grandis in Brazil under different residue management $\begin{array}{llll}\text { practices. Southern For 69: 95-102. DOI: } & \end{array}$ 10.2989/SHFJ.2007.69.2.4.289.

González-García M, Hevia A, Majada J, Rubiera F, Barrio-Anta M. 2016. Nutritional, carbon and energy evaluation of Eucalyptus nitens short rotation bioenergy plantations in northwestern Spain. IForest 9: 303310. DOI: 10.3832/ifor1505-008.

Gutiérrez-Soto MV, Pacheco A, Holbrook NM. 2008. Leaf age and the timing of leaf abscission in two tropical dry forest trees. Trees 22: 393-401. DOI: 10.1007/s00468-007-0200-9. 
Hakamada R, Giunti Neto C, de Lemos CCZ, Silva SR, Otto MSG, Hall KB, Stape JL. 2016. Validation of an efficient visual method fo estimating leaf area index in clonal Eucalyptus plantations. Southern For 78: 275-281. DOI: 10.2989/20702620.2016.1201641.

Hakamada R, Hubbard RM, Ferraz S, Stape JL. 2017. Biomass production and potential water stress increase with planting density in four highly productive clonal Eucalyptus genotypes. Southern For 79: 251-257. DOI: $10.2989 / 20702620.2016 .1256041$

Halomoan SST, Wawan, Adiwirman. 2015. Effect of fertilization on the growth and biomass of Acacia mangium and eucalyptus hybrid ( $E$. grandis $x \quad E$. pellita). J Trop Soils 20: 157-166. DOI: 10.5400/jts.2015.20.3.157

Harwood CE, Alloysius D, Pomroy P, Robson KW, Haines MW. 1997. Early growth and survival of Eucalyptus pellita provenances in a range of tropical environments, compared with E. grandis, E. urophylla and Acacia mangium. New For 14: 203-219.

Hii SY, Ha KS, Ngui ML, Ak Penguang S, Duju A, Teng XY, Meder R. 2017. Assessment of plantation-grown Eucalyptus pellita in Borneo, Malaysia for solid wood utilisation. Austr For 80: 26-33. DOI: 10.1080/00049158.2016.1272526.

Houghton RA, Hall F, Goetz SJ. 2009. Importance of biomass in the global carbon cycle. J Geophys Res Atmos 114 (3): G00E03. DOI: 10.1029/2009JG000935.

Hung TD, Brawner JT, Meder R. 2015. Estimates of genetic parameter for growth and wood properties in Eucalyptus pellita F. Muell. to support tree breeding in Vietnam. Annals For Sci 72: 205-217. DOI: 10.1007/s13595-014-0426-9.

Karavin N. 2013. Effects of leaf and plant age on specific leaf area in deciduous tree species Quercus cerris L. var. cerris. Bangladesh J Bot 42: 301-306. DOI: 10.3329/bjb.v42i2.18034.

Kaul M, Mohren GMJ, Dadhwal VK. 2010. Carbon storage and sequestration potential of selected tree species in India. Mitig Adap Strateg Global Change 15: 489-510. DOI: 10.1007/s11027-010-92305.

Kohl M, Neupane PR, Lotfiomran N. 2017. The impact of tree age on biomass growth and carbon accumulation capacity: A retrospective analysis using tree ring data of three tropical tree species grown in natural forests of Suriname. PLoS One 12 (8): e0181187. DOI: 10.1371/journal.pone.0181187

Kweon D, Comeau PG. 2019. Relationships between tree survival, stand structure and age in trembling aspen dominated stands. For Ecol Manage 438: 114-122. DOI: 10.1016/j.foreco.2019.02.003.

Laclau JP, Almeida JCR, Gonalves JLM, Saint-Andr L, Ventura M, Ranger J, Moreira RM, Nouvellon Y. 2009. Influence of nitrogen and potassium fertilization on leaf lifespan and allocation of above-ground growth in eucalyptus plantations. Tree Physiol 29: 111-124. DOI: 10.1093/treephys/tpn010.

Latifah S, Muhdi M, Purwoko A, Tanjung E. 2018. Estimation of aboveground tree biomass Toona sureni and Coffea arabica in agroforestry system of Simalungun, North Sumatra, Indonesia Biodiversitas 19: 620-625. DOI: 10.13057/biodiv/d190239.

Lewis JD, Phillips NG, Logan BA, Hricko CR, Tissue DT. 2011. Leaf photosynthesis, respiration and stomatal conductance in six eucalyptus species native to mesic and xeric environments growing in a common garden. Tree Physiol 31: 997-1006. DOI 10.1093/treephys/tpr087.

Li G, Zhang Z, Shi L, Zhou Y, Yang M, Cao J (2018). Effects of different grazing intensities on soil $\mathrm{C}, \mathrm{N}$, and $\mathrm{P}$ in an Alpine Meadow on the Qinghai — Tibetan. Int J Environ Res Public Health 15 (11): 2584 DOI: 10.3390/ijerph15112584

Lima PR, Malavasi UC, Battistus AG, Dranski JAL, De Matos Malavasi M. 2019. Photosynthetic responses of Eucalyptus seedlings submitted to chemical and mechanical stimulus. Ciencia Florestal 29: 740-753. DOI: $10.5902 / 1980509830685$.

Little KM, Ahtikoski A, Morris AR, Little KM, Ahtikoski A, Rotationend ARM, Little KM, Ahtikoski A, Morris AR. 2018. Rotation-end financial performance of vegetation control on Eucalyptus smithii in South Africa smithii in South Africa. Southern For 80: 241-250. DOI: 10.2989/20702620.2017.1341114.

Magalhães TM, Cossa VN, Guedes BS, Fanheiro ASM. 2020. Speciesspecific biomass allometric models and expansion factors for indigenous and planted forests of the Mozambique highlands. J For Res 32: 1047-1065. DOI: 10.1007/s11676-020-01156-0.

Maimunah S, Rahman SA, Samsudin YB, Artati Y, Simamora TI, Andini S, Lee SM, Baral H. 2018. Assessment of suitability of tree species for bioenergy production on burned and degraded peatlands in Central Kalimantan, Indonesia. Land 7: 1-14. DOI: 10.3390/land7040115.

McTague JP, Weiskittel AR. 2016. Individual-tree competition indices and improved compatibility with stand-level estimates of stem density and long-term production. Forests 7 (10): 238. DOI: 10.3390/f7100238.

Nambiar EKS, Harwood CE, Mendham DS. 2018. Paths to sustainable wood supply to the pulp and paper industry in Indonesia after diseases have forced a change of species from acacia to eucalypts. Austr For 81: 148-161. DOI: 10.1080/00049158.2018.1482798.

Nandini R, Narendra BH. 2017. Critical land characteristics of former eruption of Batur Mount in Bangli District, Bali. Jurnal Penelitian Hutan dan Konservasi Alam 9: 199-211. DOI: 10.20886/jphka.2012.9.3.199-211.

Nguyen TT, Arndt SK, Baker PJ. 2019. Leaf physiological responses to drought stress and community assembly in an Asian Savanna. Forests 10 (12): 1119. DOI: 10.3390/f10121119.

Poorter H, Niklas KJ, Reich PB, Oleksyn J, Poot P, Mommer L. 2012. Biomass allocation to leaves, stems and roots: Meta-analyses of interspecific variation and environmental control. New Phytologist 193: 30-50. DOI: 10.1111/j.1469-8137.2011.03952.x.

Prasetyo A, Aiso H, Ishiguri F, Wahyudi I, Wijaya IPG, Ohshima J, Yokota S. 2017. Variations on growth characteristics and wood properties of three Eucalyptus species planted for pulpwood in Indonesia. Tropics 26: 59-69. DOI: 10.3759/tropics.ms16-15.

Pretzsch H, Biber P, Uhl E, Dahlhausen J, Rötzer T, Caldentey J, Koike T, van Con T, Chavanne A, Seifert T, Toit B du, Farnden C, Pauleit S. 2015. Crown size and growing space requirement of common tree species in urban centres, parks, and forests. Urban For Urban Greening 14: 466-479. DOI: 10.1016/j.ufug.2015.04.006.

Rance SJ, Mendham DS, Cameron DM. 2017. Assessment of crown woody biomass in Eucalyptus grandis and E. globulus plantations. New For 48: 381-396. DOI: 10.1007/s11056-016-9563-3.

Rosbakh S, Römermann C, Poschlod P (2015). Specific leaf area correlates with temperature: New evidence of trait variation at the population, species and community levels. Alpine Bot 125: 79-86. DOI: $10.1007 / \mathrm{s} 00035-015-0150-6$.

Sadono R, Wardhana W, Wirabuana PYAP, Idris F. 2021a. Allometric equations for estimating aboveground biomass of Eucalyptus urophylla S.T. Blake in East Nusa Tenggara. J Trop For Manag 27: 24-31. DOI: 10.7226/jtfm.27.1.24.

Sadono R, Wardhana W, Wirabuana PYAP, Idris F. 2021b. Soil chemical properties influences on the growth performance of Eucalyptus urophylla planted in dryland ecosystems, East Nusa Tenggara. J Degraded Mining Lands Manag 8: 2635-2642. DOI: 10.15243/jdmlm.2021.082.2635

Sasaki N, Asner GP, Pan Y, Knorr W, Durst PB, Ma HO, Abe I, Lowe AJ, Koh LP, Putz FE. 2016. Sustainable management of tropical forests can reduce carbon emissions and stabilize timber production. Front Environ Sci 4: 1-13. DOI: 10.3389/fenvs.2016.00050.

Simetti R, Bonduelle GM, Silva DA da, Mayer SLS, Souza HP, Muniz GIB de. 2018. Production of biomass and energy stock for five Eucalyptus species. Revista Ciência Da Madeira - RCM 9: 30-36. DOI: $10.12953 / 2177-6830 /$ rcm.v9n1p30-36.

Stanturf JA, Vance ED, Fox TR, Kirst M. 2013. Eucalyptus beyond its native range: Environmental issues in exotic bioenergy plantations. Int J For Res 2013: 463030. DOI: 10.1155/2013/463030.

Stuepp CA, Kratz D, Gabira MM, Wendling I. 2020. Survival and initial growth in the field of eucalyptus seedlings produced in different substrates. Pesquisa Agropecuaria Brasileira 55: 1-12. DOI: 10.1590/S1678-3921.pab2020.v55.01587.

Thompson IM. 2013. Early growth results of three Eucalyptus grandis $\times$ Eucalyptus nitens hybrid clonal trials and their response to snow events. Southern For 75: 185-188. DOI: 10.2989/20702620.2013.820446.

Truax B, Fortier J, Gagnon D, Lambert F. 2018. Planting density and site effects on stem dimensions, stand productivity, biomass partitioning, carbon stocks and soil nutrient supply in hybrid poplar plantations. Forests 9 (6): 293. DOI: 10.3390/f9060293.

Van Bich N, Mendham D, Evans KJ, Dong TL, Hai VD, Van Thanh H, Mohammed CL. 2019. Effect of residue management and fertiliser application on the productivity of a Eucalyptus hybrid and Acacia mangium planted on sloping terrain in northern Vietnam. Southern For 81: 201-212. DOI: 10.2989/20702620.2018.1555940.

Versini A, Zeller B, Derrien D, Mazoumbou J, Laclau J. 2014. The role of harvest residues to sustain tree growth and soil nitrogen stocks in a 
tropical Eucalyptus plantation. Plant Soil 376: 245-260 DOI: 10.1007/s11104-013-1963-y.

Viera M, Rodríguez-Soalleiro R. 2019. A complete assessment of carbon stocks in above and belowground biomass components of a hybrid Eucalyptus plantation in Southern Brazil. Forests 10 (7): 536. DOI: 10.3390/f10070536.

Visser L, Hoefnagels R, Junginger M. 2020. The potential contribution of imported biomass to renewable energy targets in the EU-the trade-off between ambitious greenhouse gas emission reduction targets and cost thresholds. Energies 13 (7):1761. DOI: 10.3390/en13071761.

Wirabuana PYAP, Sadono R, Juniarso S, Idris F. 2020a. Interaction of fertilization and weed control influences on growth, biomass, and carbon in eucalyptus hybrid (E. pellita $\times$ E. brassiana $)$. J Trop For Manag 26: 144-154. DOI: $10.7226 / \mathrm{jtfm} .26 .2 .144$.

Wirabuana PYAP, Sadono R, Jurniarso S. 2019. Fertilization effects on early growth, aboveground biomass, carbon storage, and leaf characteristics of Eucalyptus pellita F.Muell. in South Sumatra. J Trop For Manag 25: 154-163. DOI: 10.7226/jtfm.25.3.154.
Wirabuana PYAP, Setiahadi R, Sadono R, Lukito M, Martono DS, Matatula J. 2020b. Allometric equations for estimating biomass of community forest tree species in Madiun, Indonesia. Biodiversitas. 21: 4291-4300. DOI: 10.13057/biodiv/d210947.

Xiao CW, Janssens IA, Curiel Yuste J, Ceulemans R. 2006. Variation of specific leaf area and upscaling to leaf area index in mature Scots pine. Trees 20: 304-310. DOI: 10.1007/s00468-005-0039-x.

Xie Y, Wang X, Silander JA. 2015. Deciduous forest responses to temperature, precipitation, and drought imply complex climate change impacts. Proceedings of the National Academy of Sciences of the United States of America 112: 13585-13590. DOI: 10.1073/pnas.1509991112.

Zhu W, Xiang W, Pan Q, Zeng Y, Ouyang S, Lei P, Deng X, Fang X, Peng C. 2016. Spatial and seasonal variations of leaf area index (LAI) in subtropical secondary forests related to floristic composition and stand characters. Biogeosciences 13: 3819-3831. DOI: 10.5194/bg13-3819-2016. 